\title{
A Comparative Study on the Antimicrobial Activity of Natural and Artificial (Adulterated) Honey Produced in Some Localities in Ghana
}

\author{
Matthew Glover Addo*, Abdul Hakim Mutala and Kingsley Badu \\ Department of Theoretical and Applied Biology, Kwame Nkrumah University of Science and \\ Technology, Kumasi, Ghana \\ *Corresponding author
}

\section{A B S T R A C T}

\begin{tabular}{|c|}
\hline $\begin{array}{l}\text { K e y w o r d s } \\
\text { antimicrobial, } \\
\text { adulterated, } \\
\text { antioxidant, } \\
\text { moisture content, } \\
\text { susceptibility }\end{array}$ \\
\hline Article Info \\
\hline $\begin{array}{l}\text { Accepted: } \\
05 \text { April } 2020 \\
\text { Available Online: } \\
10 \text { May } 2020\end{array}$ \\
\hline
\end{tabular}

The study measured and compared quality parameters such as $\mathrm{pH}$, moisture content, ash content and hydrogen peroxide concentration of three types of honey from different localities in Ghana. Using the agar well diffusion, antimicrobial potential of natural honey from two different sources as well as an adulterated honey were determined against Staphylococcus aureus (ATCC 25923), Escherichia coli(ATCC 35218)and Klebsiella pneumonia (ATCC 27736). The results of the physico-chemical properties showed the following range of values; $\mathrm{pH}$ of (3.68-4.49), moisture content $(17.20-22.42 \%)$ and ash content $(0.09-0.48 \%)$. The moisture content of the adulterated samples at $25 \%$ and $50 \%$ concentration in all cases exceeded the recommended $21 \%$ of good quality honey. The findings also indicated that, natural honey (Koforidua and Berekum) has a higher antimicrobial activity against all the bacteria compared to the adulterated honey. The susceptibility of Escherichia coli, to the honey treatment, was significantly different ( $\mathrm{p}=0.0383$ ) from $S$. aureus and $K$. pneumoniae. However, when the susceptibility of $S$. aureus and $K$. pneumoniae, when compared was insignificant $(\mathrm{p}=0.6292)$. The adulteration of the honey could have caused some of the antibacterial factors in the honey to be lost or reduced to non-lethal amounts, hence losing it antimicrobial properties.

\section{Introduction}

Honey has been recognized and used as a form of antimicrobial agent for centuries (Hegazi, 2011).It has been discovered to be used as therapeutic agent for wound healing potential (Jalali et al., 2007), treatment of gastroenteritis in infants (Brady et al., 2004) and liver disease (Frankel et al., 1998) due to its antioxidant activity (Atrooz, et al., 2008). These therapeutic potentials are partly attributed to the enzymatic production of hydrogen peroxide, the low $\mathrm{pH}$ and high sugar content (Molan, 1992). These physiochemical properties are known to obstruct the growth of most clinical and environmental microorganism (Mullai and Menon, 2007). 
In recent times, the potent activity of honey against certain antibiotic-resistant bacteria has increased the awareness for the application of honey as a therapeutic product (Kwakman et al., 2011).

The quality of honey determines its acceptability which can be assessed by among other things, its physicochemical characteristics (Muruke, 2014). Shahnawaz (2013) and other studies have shown that the quality of honey is based on its physicochemical characteristics. Normally, natural honey is sticky and viscous with water content of $15-20 \%$, $\mathrm{pH}$ of 3-5, sugar content of $65 \%$ and above, high viscosity, hydroxymethyl furfural (HMF) levels not exceeding $40 \mathrm{mg} / \mathrm{kg}$ and ash content of up to 0.6\% (Codex Alimentarius Commission, 2001).

However, there are reports of the decline in quality of the honey in the open market due to the possible adulteration of these honeys being sold commercially as genuine products.A careful preliminary observation of the open market honey reveals off colors and sometimes a different taste and thickness compared to natural honey. Since pure honey is known to have antimicrobial properties, consumers of such products may rely on the questionable product in the market as antibacterial agents in the treatment of wounds and infections which may prove futile. This is because adulterated honey may have a relatively low antimicrobial and other healing properties as compared to natural or pure honey (Al-Waili et al., 2012).There is scanty research in Ghana to assess the quality of honey produced for domestic consumption based on its physicochemical properties.As a result, it is very necessary to investigate and compare the antimicrobial activity of the honey in the open market to the pure or natural honey. This study therefore, seeks to assess the physicochemical properties of both the natural and artificial (adulterated) honeys in relation to their antimicrobial activity by comparing the antimicrobial activity of the natural and adulterated honey from different localities in Ghana.

\section{Materials and Methods}

\section{Collection of honey samples}

Three different honey samples were used for this experiment comprising of two pure/natural honey samples sourced from different geographic regions namely the Berekum beehive in Brong Ahafo and Koforidua beehive in the Eastern region. The other honey was purchased in the open market at Ayeduase, a suburb of Kumasi. The vegetation of the various sample sites was noted and recorded. All the samples were stored in an opaque black polythene bag and under room temperature during the period of the investigation.

\section{Measurement of pH}

The $\mathrm{pH}$ of honey samples was done in triplicates and determined using a digital portable pH meter - Thermo Scientific RUSSEL RL 060P in accordance with AOAC $(2,000)$. In between the readings of different samples, the electrode was washed with distilled water and dried with tissue paper. All honey samples were diluted to $75 \%$. $50 \%$ and $20 \%$.

\section{Moisture content determination}

Moisture content was determined using a standard method described by AOAC (2000). About $2 \mathrm{ml}$ of honey samples in triplicates were put in pre-weighed dried crucibles, kept overnight in an oven at $110{ }^{\circ} \mathrm{C}$ and weighed. The loss in weight was taken as a measure of moisture content (Shahnawaz et al., 2013) calculated by the following formula 


$$
\text { Moisture }(\%)=\frac{(\text { Weight of Fresh Sample }- \text { Weight of Dry Sample) }}{\text { Weight of Fresh Sample }} \times 100
$$

\section{Determination of ash content}

The standard method by AOAC (2000) was followed in the determination of honey ash content. 3 grams of honey were put in dried pre-weighed crucibles and were heated in a furnace at $500{ }^{\circ} \mathrm{C}$ for 5 hours, until ash samples produced became white or greyish white. The ashed samples were placed in desiccators and allowed to cool and then weighed. The percentage ash content was calculated as:

$$
\text { Ash Content }(\%)=\frac{\text { (Weight of Sample after Ashing) }}{\text { Weight of Fresh Sample }} * 100
$$

Measurement of Hydrogen peroxide concentration

The hydrogen peroxide content of the three honey samples were determined by adding $0.1 \mathrm{~g}$ of potassium iodide (KI) to acetic acid $\left(\mathrm{CH}_{3} \mathrm{COOH}\right)$ to form a mixture. To this mixture, $1 \mathrm{ml}$ of the honey was added and observed. Yellowish or very light brown foam indicates a low peroxide concentration in the sample and brown foam shows a high concentration of hydrogen peroxide in the sample.

\section{Bacterial isolates}

The Bacteria used in this study were obtained from the Microbiology laboratory of the Pharmacy Department of the Kwame Nkrumah University of Science and Technology. Three plates of each bacteria cultures were prepared to test against each of the three honey samples. Escherichia coli (ATCC 35218) was cultured in MacConkey agar and incubated at $37^{\circ} \mathrm{C}$ for 24 hours.
Staphylococcus aureus (ATCC 25923) was cultured in Mannitol Salt agar and incubated at $37^{\circ} \mathrm{C}$ for 24 hours. Klebsiella pneumonia (ATCC 27736) was cultured in MacConkey agar and incubated at $37^{\circ} \mathrm{C}$ for 24 hours.

\section{Antimicrobial activity}

Antibacterial activities of the different honeys were determined by direct assay procedure (Gulfraz et al., 2011). Cultures of each bacteria were prepared to test for their susceptibility to the three different honey samples. In each petri dish, wells of $14 \mathrm{~mm}$ diameter were created in the agar with a cork borer to accommodate the four different concentrations of each honey sample. Each of the wells was labeled to avoid mixing up the positions of the different honey concentrations.

The various concentrations of each honey sample were then placed in their respective wells and the entire set up was incubated at $37^{\circ} \mathrm{C}$ for 24 hours and then observed for any inhibition zone. The zone of inhibition was obtained by measuring the distance from the circumference of the well to the circumference of the clear zone formed around the well.

\section{Statistical analysis}

All analyses were performed in triplicates and data was presented as mean standard deviation. Differences in performance between honey samples were analyzed using analysis of variance (ANOVA) determined by IBM SPSS Statistics version 22.

The mean zones of inhibition of honey were also compared with that of the various antibiotics using Analysis of Variance (ANOVA) to determine the significant differences. Differences at $\mathrm{P}<0.05$ were considered statistically significant. 


\section{Results and Discussion}

\section{Physical examination of honey samples}

The different honey samples were physically examined and the results summarized in Table 1. The parameters that were observed included the colour, viscosity and the presence of suspended particles. The purity of the samples was also indicated.

\section{pH, moisture and ash content of honey samples}

The $\mathrm{pH}$ of the honey samples was determined before they were used in the experiment. The general $\mathrm{pH}$ was acidic with a range of 3.69 4.49. The results of the $\mathrm{pH}$ measurements for each sample are represented in Table 2.There were varied moisture content of honey samples from 17.20 to $22.42 \%$. On the average, the moisture content of all the samples was below $21 \%$. The values obtained for the ash content varied from 0.10 to $0.48 \%$, with the artificial honey having the highest ash content $(0.48 \%)$ while sample from Brekum had the least $(0.09 \%)$ all at $25 \%$ concentration (Table 2).

\section{Concentration of hydrogen peroxide in the honey samples}

There was no hydrogen peroxide in the adulterated honey. The honey collected from Koforidua and Berekum had some concentration of hydrogen peroxide. Koforidua honey recorded the highest concentration of hydrogen peroxide whilst that from Berekum had a lower concentration of hydrogen peroxide (results not shown).

Susceptibility of the microorganisms to the different concentrations of honey used in the experiment

Antimicrobial sensitivity of the microorganisms to the honey concentrations was determined using the agar well diffusion method. S. aureus (ATCC 25923)recorded the highest zones of inhibition in all concentrations against Koforidua pure honey. Artificial honey had the least potency against organisms tested, with honey from Berekum being the intermediate.

The zones of inhibition declined with a decrease in concentration of the honey sample. The only exception was seen with Berekum pure honey at $25 \%$ and $50 \%$. Figure 1 shows the decline of the zone of inhibition upon dilution of honey and also the potency of the different types of honey against $S$. aureus.

Koforidua honey and Berekum honey recorded similar zones of inhibition $(2 \mathrm{~mm}$ at $100 \%$ and $1 \mathrm{~mm}$ at $75 \%$ ) against $E$. coli(ATCC 35218), as shown in Figure 2, with adulterated honey showing the least activity. $25 \%$ honey of all the samples did not give any zone of inhibition $(0 \mathrm{~mm})$. With $E$. coli as well, activity can be seen to decline with decrease in concentration of honey. Figure 3 shows the sensitivity of $K$. pneumoniae to the different types of honey.

At $100 \%$, the activity of Koforidua honey against organism was the highest among the three honey samples with a zone of inhibition of $5 \mathrm{~mm}$. However, there was a sudden decline in its activity upon dilution with no activity at all at $50 \%$ and $25 \%$. Berekum honey showed a steady decline in the inhibition with dilution. Adulterated honey had the least antibacterial activity at $100 \%$ compared to the other honeys but inhibited $K$. pneumoniae at $50 \%$ whereas Koforidua did not at the same concentration.

The least sensitive bacteria to the honey treatment was E. coli as seen in Figure 4. The inhibition of $S$. aureus and $K$. pneumoniae 
was of slight difference with Koforidua honey being the most potent honey against them, followed by Berekum honey. Figure 4 shows the sensitivity of each microorganism to $100 \%$ honey treatment.

\section{Discussion}

Honey has been recognized to have antibacterial activity, nevertheless there is a huge discrepancy in the potencies of different honeys and also the potential to inhibit bacterial growth. Physical examination revealed noticeable differences in colour between the honey samples from Koforidua, Berekum and the adulterated honey used in the study. Koforidua honey which was the darkest in colour recorded higher $\mathrm{pH}$ values and had a stronger flavor relative to the lighter coloured Berekum honey.

This trend was consistent with a number of studies which elaborate on the importance of honey colour in qualitative grading of different honeys. Reports have indicated that, dark honeys are characterized by having higher $\mathrm{pH}$ values, antioxidant activity and phenolic content than lighter honeys which are known to contain higher amount of sugars (Maeda et al., 2005; Eleazu, 2012).

Dark honeys are also found to be richer in minerals, especially iron, manganese and copper, making them more suitable for medicinal purposes (Bouldini et al., 2001). Furthermore, darker honeys tend to have stronger flavours compared to lighter honeys (Muruke, 2014).An assessment of the thickness of the honey samples revealed the three honey samples to be relatively viscous.

However, Koforidua and Berekum honey were thicker than the artificial honey. Moisture content of natural honey has been proposed to be less than $21 \%$ by the Codex Alimentarius (2001) which would render honey highly viscous. The low moisture content of the honey has a role in its own shelf-life and its antibacterial potential. The artificial honey was less thick than the two natural honey samples which implied that water had been added during its processing. Nyau et al., reported in 2013 that, honey with a high moisture content indicated adulteration and this supports the claim that the adulterated honey used in this study had a higher water activity than the natural honeys.

Studies have also shown that moisture content of honey is one of the criteria that determine the shelf stability of honey (Azenedo et al., 2003). The values obtained for the ash content varied from 0.10 to $0.48 \%$, with the artificial honey having the highest ash content $(0.48 \%)$ while sample from Koforidua had the least $(0.10 \%)$ at $25 \%$ concentration. Vanhanen et al., 2011 reports that ash content is a reflection of the total inorganic minerals that are present in a sample after incineration.

Generally, all the types of honey used had some activity against all the selected bacteria with varying degrees of sensitivity. However, there was a decrease in antibacterial activity with a decrease in the concentration of honey used. Koforidua honey generally recorded higher zones of inhibition against the test bacteria than the Berekum honey and the adulterated honey.

This could be attributed to a higher phenolic content in darker honeys as compared to lighter honeys (Eleazu, 2012). The study demonstrated that honey indeed has antimicrobial properties, with natural honey showing more activity against bacteria than the artificial honey.

The main drivers responsible for the differences in antimicrobial potential of the pure honey from different sources and between the pure and impure honey used in 
this experiment could be the different chemical composition of the honeys resulting from differences in floral sources as well as the species of bees involved in their production. (Sohaimy et al., 2015).

In almost all the studies where two or more types of honey were used, differences were observed in the antimicrobial activities. The amount of variation seen in some cases has been large and in others, small. In this study, where different sources of honey were used, the vegetation in which the bees foraged was noted in order to establish a connection between antibacterial activity and phytochemical factors present as a result of the bees' feeding activities. These natural factors would be evidently absent or in minute concentrations in processed or adulterated honey.

The susceptibility of Escherichia coli, to the honey treatment, was significantly different $(\mathrm{p}=0.0383)$ from $S$. aureus and $K$. pneumoniae. However, when the susceptibility of $S$. aureus and $K$. pneumoniae, was compared, the difference in sensitivities to the honey treatment was insignificant $(\mathrm{p}=0.6292)$. Consistent with Maciorowski et al., (2007), E. coli was observed to have a relatively higher resistance to all the types and concentrations of honey used in this experiment.

This might be as a result of certain mechanisms employed by E.coli to survive amidst unfavourable conditions such as high osmolarity and low $\mathrm{pH}$ of the surrounding. It is able to cause an alteration of the composition of its cell wall in order to actively prevent the diffusion of ions into the cell. For this reason, E. coli is known to have a relatively high acid tolerance and can withstand $\mathrm{pH}$ ranges as low as $3.3-4.2$ because it prevents $\mathrm{H}^{+}$ions from penetrating its cell wall and disrupting its cellular processes. A study conducted by Mandal and Mandal in (2011) on the medicinal property and antibacterial activity of honey also revealed $E$. coli to be the least susceptible microorganism when it was used in an experiment together with Methicillin-resistant Staphylococcus aureus (MRSA) and $P$. aeruginosa. Staphylococcus aureus had very low resistance to the honey treatment compared to E. coli, although it is Grampositive and therefore has a thick peptidoglycan cell wall as reinforcement.

This could be partly due to the high osmolarity, hydrogen peroxide content and low $\mathrm{pH}$ of the honey samples. Its highest sensitivity which was also the highest recorded in the experiment, was against Koforidua honey which also had a high concentration of hydrogen peroxide.

This combination of factors may have caused the penetration of the peptidoglycan cell wall which resulted in the high susceptibility. The pattern observed on $S$. aureus was consistent with a study by Kwakman et al., (2011).K. pneumoniae had a similar mean zone of inhibition to $S$. aureus and their sensitivities to honey do not vary significantly.

It is known to be a Gram-negative bacterium hence there is absence of a thick peptidoglycan cell wall which makes it more vulnerable to stress in its environment. This could explain why it showed a relatively low resistance to honey.

A study conducted by Adeshina et al., in 2013 also found $K$. pneumoniae to be readily susceptible to honey treatment due to its inability to prevent the movement of disruptive ions and compound across its cell wall and also to facilitate resistant mechanisms to evade the attack on its cellular processes. 
Table.1 Physical properties of Koforidua honey, Berekum honey and adulterated honey used in the study

\begin{tabular}{|l|l|l|l|}
\hline Properties & Koforidua Honey & Berekum Honey & \multicolumn{1}{|c|}{ Adulterated Honey } \\
\hline Colour & Dark brown & Gold & Reddish brown \\
\hline Viscosity & Highly viscous & Highly viscous & $\begin{array}{l}\text { Highly viscous but } \\
\text { considerably less } \\
\text { viscous than } \\
\text { Koforidua and } \\
\text { Berekum honey }\end{array}$ \\
\hline Suspended particles & $\begin{array}{l}\text { Many suspended } \\
\text { particles were present } \\
\text { in the honey sample }\end{array}$ & $\begin{array}{l}\text { Few suspended } \\
\text { particles were present } \\
\text { in the honey sample }\end{array}$ & $\begin{array}{l}\text { No suspended } \\
\text { particles were present } \\
\text { in the sample }\end{array}$ \\
\hline Purity & $\begin{array}{l}100 \% \text { raw and organic } \\
100 \% \text { organic }\end{array}$ & $\begin{array}{l}\text { Purity unknown due } \\
\text { to adulteration }\end{array}$ \\
\hline
\end{tabular}

Table.2 pH, percentage moisture and ash content of honey samples from Koforidua, Berekum and Artificial (Ayeduase) as means of triplicate determinants

\begin{tabular}{|c|c|c|c|c|}
\hline \multicolumn{5}{|c|}{ Source of Honey } \\
\hline & $\begin{array}{c}\text { Concentration } \\
(\%)\end{array}$ & Koforidua & Berekum & $\begin{array}{c}\text { Artificial } \\
\text { (Ayeduase) }\end{array}$ \\
\hline \multirow[t]{4}{*}{ pH } & 25 & 4.16 & 3.89 & 4.49 \\
\hline & 50 & 4.15 & 3.78 & 4.43 \\
\hline & 75 & 4.13 & 3.72 & 4.42 \\
\hline & 100 & 4.08 & 3.68 & 4.33 \\
\hline \multirow{4}{*}{$\begin{array}{l}\text { Moisture } \\
\text { content }\end{array}$} & 25 & 17.89 & 18.22 & 22.42 \\
\hline & 50 & 17.80 & 18.20 & 21.50 \\
\hline & 75 & 17.32 & 17.81 & 20.52 \\
\hline & 100 & 17.20 & 17.80 & 20.00 \\
\hline \multirow[t]{4}{*}{ Ash content } & 25 & 0.18 & 0.24 & 0.48 \\
\hline & 50 & 0.10 & 0.09 & 0.16 \\
\hline & 75 & 0.16 & 0.21 & 0.18 \\
\hline & 100 & 0.20 & 0.19 & 0.12 \\
\hline
\end{tabular}




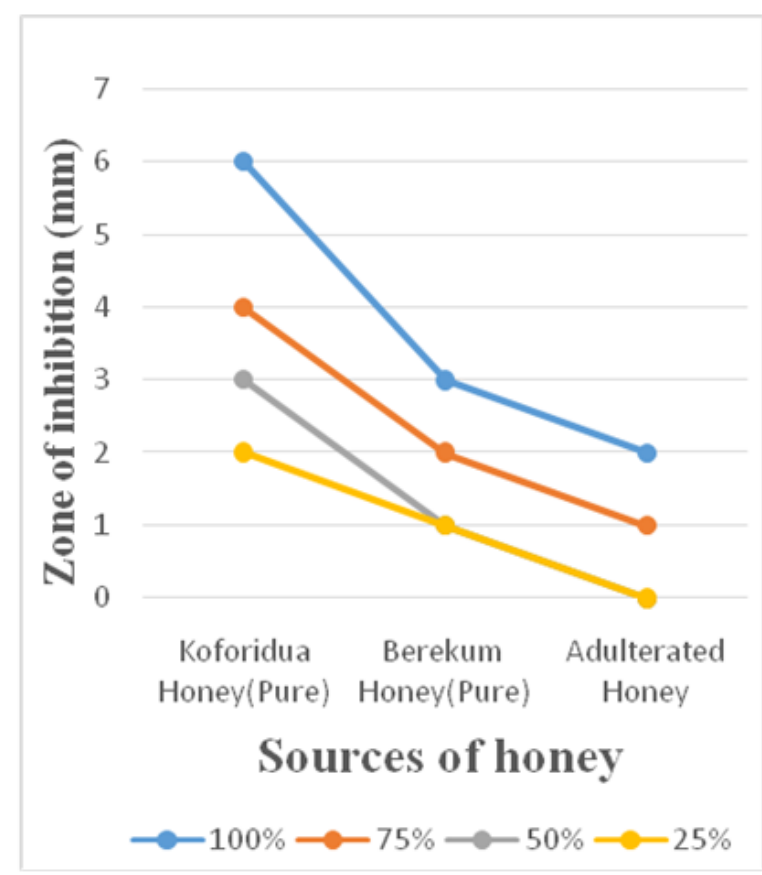

Figure.1 A comparison of the susceptibility of $S$. aureus to different concentrations of two pure honey samples and one artificial honey sample
3
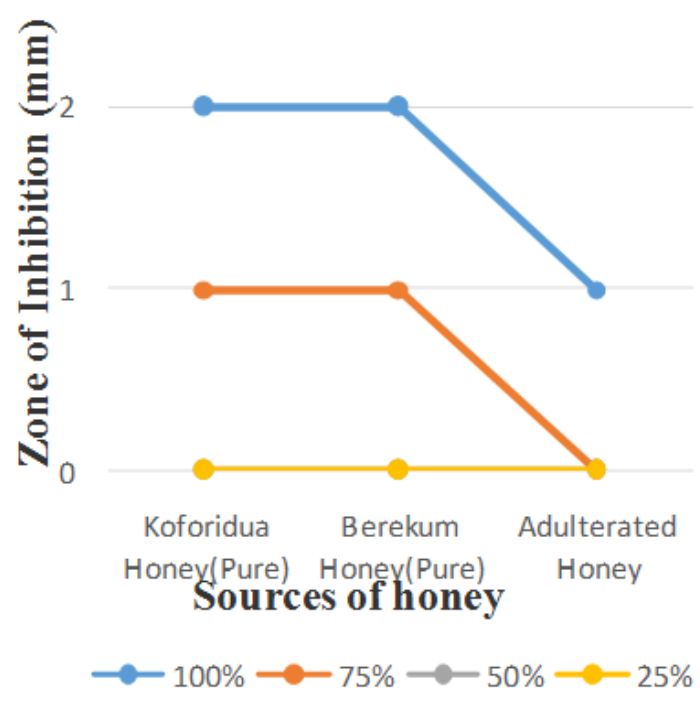

Figure.2 A comparison of the susceptibility of E. coli to different concentrations of two pure honey samples and one adulterated honey sample

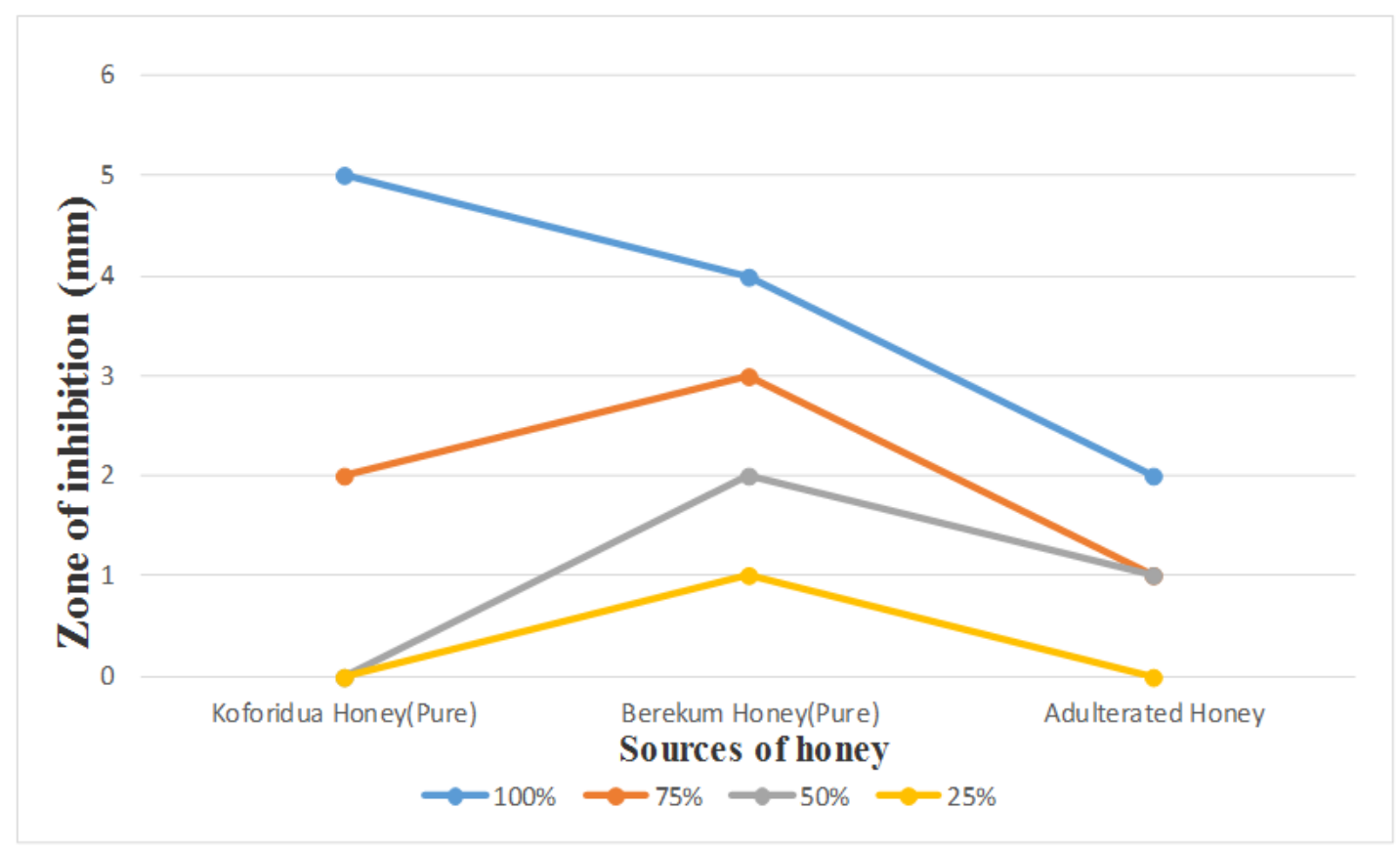

Figure.3 A comparison of the susceptibility of $K$. pneumoniae to different concentrations of two pure honey samples and one adulterated honey sample 


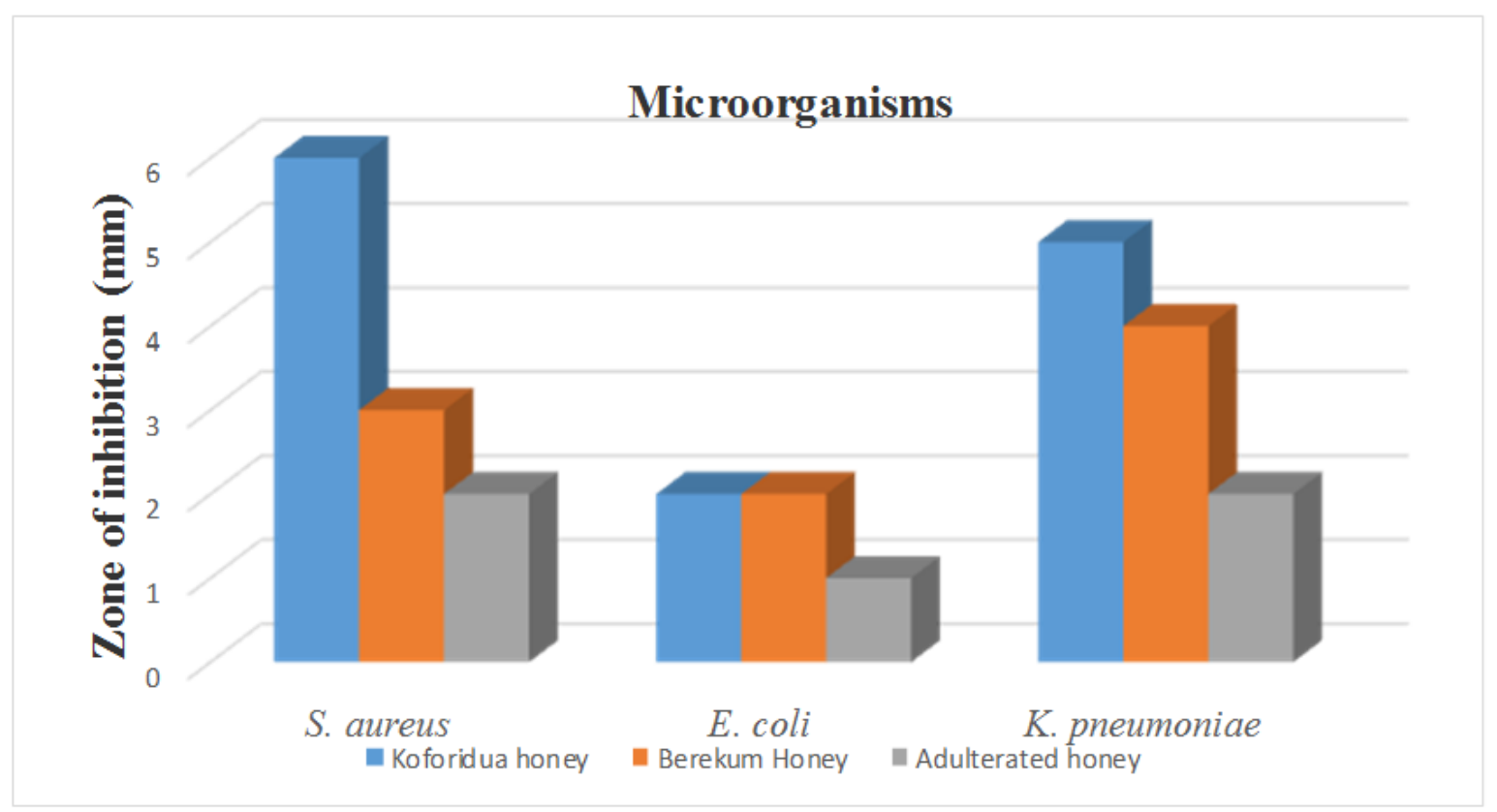

Figure.4 A comparison of the degree of sensitivity of each of the microorganisms to undiluted $(100 \%)$ honey

The study showed the variability of some quality characteristics of honey samples from the different locations in Ghana. In this work, the principal physiochemical properties such as $\mathrm{pH}$, ash content and moisture content of the three honey samples have been determined. Honey colour and moisture content are two important physicochemical parameters that may be used to assess quality of honey.

The findings also indicated that, natural honey has a higher antimicrobial activity against all the bacteria compared to the artificial or adulterated honey. The adulteration of the honey could have caused some of the antibacterial factors in the honey to be lost or reduced to non-lethal amounts, hence losing it antimicrobial properties.

\section{Acknowledgement}

The authors would like to gratefully acknowledge everyone involve in this research especially to the Technicians at the Microbiology Laboratory at the Department of Theoretical and Applied Biology, Kwame Nkrumah University of Science and Technology, Kumasi, Ghana for their guidance and support.

\section{References}

Adeshina, G. O., Mshelia, B. M. and Onaolapo, J. A. 2013. Antibacterial Susceptibility of Klebsiella pneumoniae Isolates from Respiratory Tract Infections to Honey and Lemon. Department of Pharmaceutics and Pharmaceutical Microbiology, Ahmadu Bello University,Zaria, Nigeria., 1-7.

Al-Waili, Noori, KhelodSalom, Ahmed AlGhamdi, and Mohammad Javed Ansari. 2012. Antibiotic, pesticide, and microbial contaminants of honey: human health hazards." The scientific World Journal 2012.

Atrooz, O. M., Al-Sabayleh, M. A., and AlAbbadi, S. Y. 2008. Studies on physical and chemical analysis of various honey samples and their antioxidant activities. 
Journal of Biological Sciences, 8(8), 1338-1342.

Azenedo, L., Azeredo, M., De Souza, S. and Dautra, L. 2003. Protein content and physiochemical properties in honey samples of Apis Mellifera of different floral origins. Food Chemistry 80 (2): $249-254$

Bouldini, P., Cavali, S., Mevoli, A. and Sharma, J. 2001. Ion chromatographic and volumetric determination of heavy and transition metals in honey. Food Chemistry, Volume 73:487-495

Brady, N., Molan, P., and Bang, L. 2004. A survey of non-manuka New Zealand honeys for antibacterial and antifungal activities. Journal of apicultural research, 43(2), 47-52.

Codex Alimentarius. 2001. Draft revised standard for honey (at step 10 of the codex procedure). Codex Alimentarius Commission, FAO, Rome Alinorm25: $19-26$.

Eleazu, K. 2012. Nutrient composition, polyphenolic content and free radical scavenging activities of five honey samples from NRCRI, Umudike and different location in South Eastern Nigeria., 1-3.

Frankel, S., Robinson, G. E., andBerenbaum, M. R. 1998. Antioxidant capacity and correlated characteristics of 14 unifloral honeys. Journal of Apicultural Research, 37(1), 27-31.

Guler, A., Bakan, A., Nisbet, C., and Yavuz, O. 2007. Determination of important biochemical properties of honey to discriminate pure and adulterated honey with sucrose (Saccharum officinarum L.) syrup. Food chemistry, 105(3), 1119-1125.

Gulfraz, M., Itkihar, F., Imran, M., Zeenat, A., Asif, S. and Shah, I. 2011. Compositional analysis and antimicrobia activity of various honey types of Pakistan. International Journal of Food Science and Technology 46: $263-267$.

Hegazi, A. G. (2011). Antimicrobial activity of different Egyptian honeys as comparison of Saudi Arabia honey. Research Journal of Microbiology, 6(5), 488-495.

Jalali, F. S. S., Farshid, A. A., Saifzadeh, S., andJavanmardi, S. 2007. Efficacy of intra-peritoneal administration of iranian honey in prevention of postoperative peritoneal adhesions. Asian Journal of Animal and Veterinary Advances, 2(4), 212-217.

Kwakman, P. H. S., Te Velde, A. A., de Boer, L., Vandenbroucke-Grauls, C. M. J. E., and Zaat, S. A. J. 2011. Two major medicinal honeys havedifferent mechanisms of bactericidal activity. PLoS One 6(3), e17709.

Maciorowski, K.G., Herrera, P., Jones, F. T., Pillai, S.D. and Ricke, S.C. 2007. Effects on poultry and livestock of feed contamination with bacteria and fungi. Animal Feed Science and Technology, 133, 109-136.

Maeda, A., Lamein, C. E., Romito, M., Millogo, J., Nacoulma, O. G. 2005. Determination of the total phenolic, flavonoid and proline contents in Burkina Faso honey, as well as their radical scavenging activity. Food Chem 91: 571-577.

Mandal, M. D., and Mandal, S. 2011. Honey: its medicinal property and antibacterial activity, 1(2), 154-160.

Molan, P. C. 1992. The antibacterial activity of honey: 1. The nature of the antibacterial activity. Bee world, 73(1), 5-28.

Mullai, V., and Menon, T. 2007. Bactericidal activity of different types of honey against Clinical and environmental isolates of Pseudomonas aeruginosa. The Journal of Alternative and Complementary Medicine, 13(4), 439- 
442.

Muruke, M. H. 2014. Assessment of Quality of Tanzanian Honey based on Physicochemical Properties, 33(2001), 61-73.

Nyau, V., Mwanza, P. and Moonga, B. 2013. Physico-chemical qualities of honey harvested from different beehive types in Zambia. African Journal of Food Agric. Nutrition and Development 13 (2): $7415-7427$.

Shahnawaz, M., Sheikh, S.A, Hussain, M., Razaq, A, and Khan, S.S 2013. A study of the determination of the physiochemical properties of honey from different valleys of Gilgit Baltistan. International Journal of Agriculture Science Research, 2(2): 049-05-3.

Sohaimy, S. A. El, Masry, S. H. D., and Shehata, M. G. 2015. Physicochemical Characteristics of Honey from Different Origins. Annals of Agricultural Sciences, 60(2), 279-287.

Vanhanen, L., Emmertz, A. and Savage, G. 2011. Mineral analysis of mono-floral New Zealand honey. Food Chemistry 128: $236-240$

\section{How to cite this article:}

Matthew Glover Addo, Abdul Hakim Mutala and Kingsley Badu. 2020. A Comparative Study on the Antimicrobial Activity of Natural and Artificial (Adulterated) Honey Produced in Some Localities in Ghana. Int.J.Curr.Microbiol.App.Sci. 9(05): 962-972. doi: https://doi.org/10.20546/ijcmas.2020.905.106 